\title{
The Role of University Partners in the Innovation Adoption Process to Rice Seed Farmers in Aceh Province
}

\author{
Setia Budi ${ }^{*}$, Ahmad Humam Hamid² Fajri $^{2}$ Agussabti $^{2}$ \\ ${ }^{1}$ Agribusiness Deparment of Agiculture Faculty, Malikussaleh University, North Aceh, 24355, Indonesia. \\ ${ }^{2}$ Agriculture Faculty, Syiah Kuala University, Banda Aceh 23111, Indonesia.
}

A R T I C LE INFO

\section{Research Article}

Received 10 October 2017

Accepted 16 January 2018

Keywords:

Innovation characteristic

Partner role

Rice seed farmers

Aceh Province

Production technology

*Corresponding Author:

E-mail: s.budiunimal@gmail.com

\begin{abstract}
A B S T R A C T
The role of university partners in the innovation adoption process in the implementation of agricultural extension is very necessary to get attention to realize the success of empowering rice seed farmers. The purpose of this research is (1) to know the role of universities in the process of adopting innovation in IPB 3S seedling in Aceh Province, (2) to know the perception of farmers toward the characteristics of the innovation of IPB $3 \mathrm{~S}$ varieties, and (3) to know the role of universities in the implementation process of extension agriculture to rice seed farmers. This research uses qualitative descriptive approach with data measurement using Likert scale. The results showed that in general the universities play significant role in innovation adoption process to rice seed farmers. The role is arranged by sequence; (1) implementing cultivation skill (2) strengthening farmer institution, (3) liaison with the government (4) guidance of transfer of technology, and (5) liaison with production market. Farmers perception on the characteristics of innovation optimum production technology package (IPB-Prima) IPB 3S (1) has a relative profitability, (2) easy to try, (3) conformity, (4) observable, and (5) innovation subtly level. The role of partners in the implementation of agricultural extension in sequence (1) conformity of extension materials, (2) intensity of extension, (3) appropriateness of extension method and (4) accuracy of media usage. The university should pay attention on the mechanism of facilitating technology transfer with the use of media and appropriate extension methods to rice seed farmers. The university also should build good communication with private organizations to help farmers in terms of seed price certainty produced by rice seed farmers in Aceh Province, Indonesia.
\end{abstract}

DOI: https://doi.org/10.24925/turjaf.v6i4.427-432.1609

\section{Introduction}

The agricultural sector contributes substantially to development, and can even trigger economic growth in Indonesia. In the future, agricultural development is expected to contribute more in order to reduce the gap between the rich and the poor, to expand employment opportunities, and able to take advantage of economic opportunities that occur as the impact of globalization and liberalization of the world economy.

Essentially, farmers are the main actors of agricultural development. Thus the success of agricultural development is more determined by the role of farmers themselves which in fact can not be separated from the guidance and assistance of the government and various parties.

Besides farmers, according to Arthur (1966), one of the main requirements in agricultural development is the ever-changing technology. Tesfamicheal et al. (2017) assert that "adoption of improved agricultural technologies by smallholders is considered as the main pathway for breaking poverty trap". It is also support that innovation plays an important role in agricultural development. Diffusion and adoption of innovation in a farming community is strongly influenced by the characteristics of the innovation it self. Everett (1983) argues that there are several characteristics of an innovation, namely: (1) relative advantage, (2) alignment, (3) complexity, (4) can be tried, and (5) can be observed.

Another important aspect that should be fulfilled in agricultural development is extension program. As stated by Peter et al. (2012), extension programs play a significant role in improving science accomplishment in the United States. Extension programs also play significant role on food security on this earth. It is line with Muhammad et al. (2017) who reports that one of factors responsible for low fish production in Hafizabad, Pakistan is poor fisheries extension services. 
To achieve that goal, extension programs should be done by professional extension agent. It is in line with Elliot (2014) who believe that professionalism affect agricultural extension in service delivery by creating demotivated cadres in agriculture. Robert et al. (2010) also emphasizes the need of providing potential and current agents with formal education and professional improvement in extension program. It is also compatible with Scott et al. (2006) who report that extension systems throughout the United States expect people to have advanced educations to function as extension experts.

Agricultural extension also should also utilize appropriate material, methods and media. Serah et al. (2014) believe that extension should recognizes that farmers differ in their social economic characteristics which influence the choice of extension method used. Elliot and Ephenia (2014) also assert that extension must understand and be committed to a tested conceptual framework for extension programming. Matthew and Bill (2006) also argues that in deciding a suitable IT technique for extension, an all encompassing methodology is justified that thinks about angles past innovation itself and looks at the socio-social settings of the association.

Furthermore, to achieve sufficient accomplishment, it is very essential to build an agricultural extension partnership with various parties such as universities, farmer groups and government and non-government organization. It aims to reduce responsibility and synergy between the innovation producer and the entity that will distribute innovations to farmers.

It is in line with Gana and Stephen (2001) who said that the partnership increase the effectiveness of empowerment to the community. Nancy (2003) also states that partnerships can upgrade individual and hierarchical accomplishment through more viable critical thinking and enhanced adjustment to change.

Partnership with farmer groups for instance, can be an important institution for the transformation of smallholder farming, increase productivity and incomes thereby reducing poverty (Emmanuel et al., 2015). Hakan (2015) also believe that "the other organizations, such as local administrations, producers' associations, cooperatives, can contribute to the success of sustainable agricultural marketing initiatives". Moreover, Gungor, Esen and Esra (2017) believe that involving in agricultural organizations is one of the factors affecting the farmers' bureaucratic knowledge and skills.

Based on this background, this research aims; (1) to know the perception of farmers towards innovation characteristic cultivation of rice seed varieties IPB 3S, and (2) to determine the role of the partners in the implementation of agricultural extension to seed farmers in North Aceh district of Aceh province.

\section{Materials and Methods}

This research was conducted in North Aceh regency precisely in Sawang Sub district. The population are members of group rice farmer named "Sapue Pakat" who get agricultural extension partnership program between the Government of North Aceh and university (Bogor Agriculture Institute (IPB) and Syiah Kuala University (Unsyiah). The entire population being sampled in this study are 128 farmers.
The scope of this research is limited only to see the characteristics of technological innovation IPB $3 \mathrm{~S}$ cultivating varieties to farmers seed and the role of the partners in the implementation of agricultural extension services to farmers seed IPB $3 \mathrm{~S}$. The object of this research is the member of seed farmer group who give an assessment toward the characteristics of innovation technology cultivation and the role of partners in the implementation of the extension to seed farmers.

The measurement and the analysis of the farmers' perception on the characteristics of the innovation offered by the partners to the seed farmer is done by using Likert Scale with innovation characteristics indicator. They include (1) relative advantage, (2) the level of compatibility, (3) the level of complexity, (4) can be tried and (5) can be observed and interpreted further in the discussion

The role of the partners in the implementation of agricultural extension is analysed based on indicators (1) material conformity, (2) suitability extension method (3) the accuracy of the using media and (4) extension intensity conducted by the partners that subsequently interpreted in the discussion. The questions were served in closed form by using the 5-point Likert Scale (namely strongly agree, agree, not sure, disagree and strongly diagree) in order to have affective responses.

\section{Results and Discussion}

The agricultural sector is very potential to be developed in Indonesia. To achieve that goal, it needs to support various parties to contribute in realizing modern agriculture as well as making farmers become prosper. One of the parties which expected its role was the university that became the innovation-producing machine that will be adopted by farmers in increasing the production and productivity of agricultural business. The role as an innovator is also should be combined with the effort of spreading agricultural innovation to the main actors (farmers) with a partnership approach model.

\section{The Role of University}

The role of university in the adoption innovation process done to rice seed farmers includes (1) implementation of cultivation skills training, (2) technology transfer assistance, (3) strengthening farmer institution, (4) liaison with government, and (5) liaison with production crop market. The role of agricultural university in adoption innovation process to rice seed farmers can be seen in Table 1 .

Farmers recognized that extension university partnership programs have assisted in the spread of superior seed innovations of IPB 3S varieties produced by plant breeding teams from the Bogor Agricultural Institute (IPB) and Optimum Production Technology Package (IPB-Prima). Efforts to ensure the application of the technology package is conducted by Agriculture Faculty of Syiah Kuala University and Agriculture Faculty of Malikussaleh University on the extension partnership program and agricultural fielding program. It involved six the last year bachelor and doctoral students who helped the process of innovation, extension and dissemination of innovation. 
Table 1 Value Index of Farmer Perceptions on Innovation Characteristics

\begin{tabular}{c|lcl}
\hline $\mathrm{N}$ & \multicolumn{1}{|c}{ Role of University } & Index (\%) & Interpretation \\
\hline 1 & Implementation of cultivation skill training & 82.36 & Very significant \\
2 & Technology Transfer Assistance & 78.37 & Significant \\
3 & Strengthening farmer institutions & 81.48 & Very significant \\
4 & Liaison with government & 80.66 & Very significant \\
5 & Liaison with production crop market & 57.32 & Significant \\
\hline & Average & 76.04 & Significant \\
\hline
\end{tabular}

Table 2 Value Index of Farmer Perceptions on Innovation Characteristics*

\begin{tabular}{c|lrl}
\hline No & \multicolumn{1}{|c}{ Innovation Characteristics } & Index (\%) & \multicolumn{1}{c}{ Interpretation } \\
\hline 1 & Relative advantage & 82.36 & Strongly agree \\
2 & Compability & 78.37 & Agree \\
3 & Complexity & 72.37 & Agree \\
4 & Triability & 80.66 & Strongly agree \\
5 & Observability & 76.32 & Agree \\
\hline & General Perception & 78.02 & Agree \\
\hline
\end{tabular}

*Source: Primary Data analysis, 2016

Table 3 Index Value of Farmers Perception on Partners Role in Implementing Extension*

\begin{tabular}{c|lcl}
\hline $\mathrm{N}$ & Role of Partners in implementing Agricultural Extension & Index (\%) & Interpretation \\
\hline 1 & Extension Material & 82.71 & Very Appropriate \\
2 & Extension Method & 63.37 & Appropriate \\
3 & Appropriate use of media & 78.37 & Appropriate \\
4 & The intensity of the implementation of the extension & 80.66 & Very Appropriate \\
\hline & Public perception & 76.28 & Appropriate \\
\hline
\end{tabular}

*Sources: Primary data analysis, 2016

The universities play significant role in conducting training on the cultivation of production facilities, cultivation process, postharvest manufacture and marketing of seed production breeding. Farmer at the majority of research apply a packet of cultivation technologies delivered by universities including the seeding process with the quickly seeds incubation period. At the stage of land processing, the technological package offered by universities is dominated by the use of organic fertilizer with a larger volume than the technology that has been applied by farmers. This is in line with Rupak and Md (2011) who said that the process helps develop econometric models that study the transition of chemical agriculture to organic agriculture.

In the application of legowo row planting pattern, it is still found farmers who have not completely implemented row legowo pattern. Some reasons for applying row legowo (1) are more difficult in the process of planting, (2) the farmer assumes that there is a vacant part of the field that is not utilized for planting, (3) need a tool (rope) with different sizes and difficult to find proficient labor of planting process with legowo jajar system.

Implementation of irrigation and fertilization system does not face many obstacles by introducing intermittent irrigation techniques and water draining 10 Days before harvest. Similarly, in the case of fertilization, only the time and volume of giving that not all farmers apply it appropriately. On the other hand, there is one kind of fertilizer recommended by Optimum Production Technology which is 1 liter / Ha silica fertilizer which is sprayed at age 14 and 30 HST (Day Ready Planting) because farmers have difficulty to get it at agriculture shop in their environment. In general, what is conveyed in training activities conducted by the high level (IPB,
Unsyiah, Unimal) has been applied by the majority of farmers.

The role of universities in the assistance of the transfer of technology is considered in the significant category. The farmers perceive, although not all phases of cultivation activities get a sufficient portion in the accompaniment of the transfer of technology, there are several tiers that are considered play a role in the transfer of technology. For example, the university and farmers actively monitoring to anticipate various diseases and pest attacks. Only snail attack and caterpillar attack perceived by farmers planting I and II. However, because it is quickly detected, the preventive and pest control efforts can be done well based on the information of the extension staff from the university that always accompanied farmers in the research location. However, farmers hope that the extension not only focus on pest and disease but also focus on land management until postharvesting.

Farmers also perceive that the university play very significant role in strengthening farmer Institution. The most prominent role is to initiate the birth of a jointowned enterprise of farmer groups (Gapoktan) as well as the improvement of farmer group's management through the management training of farmers group. Besides, to strengthen the management of the group, the university actively builds communication with the local government to involve the members of the partner farmer group in training, exhibition and field visit activities aimed at improving farmers' skills and insights. One of the activities done is presenting the extension of self-help from gapoktan to attend the training conducted by the universityin the Bogor Agricultural Institute (IPB) in Sukamandi, West Java. 
The role of university as liaison of farmer with government is felt very significant. It supports John (2000) who found that The Community Development Division of the Ohio State University Extension Service helps individuals and communities to identify and meet local needs with useful information, educational programming, planning, and practical implementation.

The present research found that the liaison' farmer with government is started from planning program stage until harvesting. Farmers believe that the universities are able to convince the local governments to give confidence to the farmers to produce high quality seedlings (blue label) which is then ready for use by rice farmers in the district of North Aceh in particular and the Aceh province in general.

In contrast, the perception of farmers toward university in terms of liaison in marketing the products that are in the enough category. Although all the seeds produced can be accommodated by farmer group initiated the establishment by the university, but the farmers feel the lack of the university role in ensuring the selling price of the seed produced by farmers. When socialization program, farmers were promised to get a relatively high price. However, when the harvest, the business entities belonging to the village accommodate the price slightly lower than that promised at the beginning of the program. This happened because there is no large scale companies which accommodate the crops of seed farmers.

However, the government buy the seeds but the price is slightly below that that promised by the university at the beginning of the program. The low price obtained by farmers can be compensated with increased production compared with the application of previous innovation technology practiced by farmers. The yield of rice production using Optimum Technology (IPB-Prima) product varieties of IPB $3 \mathrm{~S}$ reached an average of 7.5 tons/ha, while the previous technology applied by farmers only reached 5.8 tons/ha.

\section{Characteristics of Innovation}

Result of research about general perception of farmer of rice varieties of IPB $3 \mathrm{~S}$ about characteristic of innovation especially cultivation technology IPB $3 \mathrm{~S}$ varieties of research location is in agree category. This shows the usefulness of innovation given by university felt benefit by the target audience. The values index of farmers perceptions on innovation characteristics can be seen on Table 2.

Table 2 shows that seed farmers IPB 3S believe that the application of technology implemented by the partners has a relative advantage compared with the innovations implemented so far by the farmers in seed multiplication activities. Seed farmers also argue that the innovation given by the partners is very easy to be tried on a small scale. It is in accordance with Agussabti (2002) who believe that innovation which can be tried on a small scale more quickly accepted by farmers than innovation that cannot be tried first.

Further, the characteristics combability and observability are in agree category where innovation given does not contradict with the experience and the values espoused by the seed farmer. The complexity of the innovation is slightly felt by farmer in both in the application of technology such as planting pattern Legowo row type 3: 1 as well as the time and volume of fertilization. At the optimum production technology IPB $3 \mathrm{~S}$ varieties, organic fertilizer is recommended relatively larger than usually done by the farmer over the years. The condition is not a significant issue in which farmers argue although initially there was little perceived complexity of the innovation provided by the partners, but it is covered by production output that higher than the previous technology implemented.

Aside from the characteristics of innovation, this research also get an overview of the role of the partners in the implementation of the extension to seed farmers varieties IPB $3 \mathrm{~S}$ covering; the suitability of the material extension, extension methods, the use of media accuracy and intensity of extension. Results of index farmer's perception of the role of the partners in the implementation of the extension can be seen in Table 3.

Seed farmer argues that extension materials delivered by the partners are appropriate to their needs. The materials are given in stages in accordance with the process of cultivation and farming needs that do the farmers began to raise awareness of the business, the business motivation, stages of cultivation, harvest management, marketing and the strengthening of the group. The Materials provided by the agency of agricultural extension and food security of North Aceh Regency as well as from the source of innovation in University (IPB and Unsyiah) also contribute to provide training and extension materials through guidance in the application of innovation technology cultivation and development of rice seed farming.

The same condition is also felt by the farmers related to the intensity of agricultural extension. Usually the extension is only done by the government, but through the partnership, the extension is also provided by the university ranging from socialization program, implementation program and evaluation of the partnership implementation.

Seed farmer argues that extension method used began with lectures, demonstrations of way and visit exercise is useful for them. It supports Patcha, Somsri and Ganjanes (2017) who reported "the extension services provided to farmers were very comprehensive, ranging from demonstration plots to training and meetings, with multimedia educational materials as well as regular field visits for monitoring and technical consultations".

However variety of extension methods have not been effective in resolving all cultivation technical issues. The method which directly provide tangible proof of cultivation technology such as plots demonstration and visit to a rice seed treatment is felt important to add in variety of using extension method and able to provide effective absorption of innovation and information by the farmers.

This is in line with Sapar et al. (2012) who believed that successful extension should be capable in designing materials and methods in accordance with the needs, conditions and characteristics of farmers. Mohammad (2013) also argues that agricultural extension must consider environmental implications, social issues, and overall economic growth within the agriculture sector. In that case, the material of leadership, technology 
dissemination and mastery of the technical areas should be controlled by extension organizer. Elliot and Ephenia (2014) also suggest that extension should provide technical knowledge and information to assist farmers to improve their farming. The information can be related to crops, animal, economics, and natural resources.

The accuracy of using media is in final sequence in the farmer's perception of the partners' role. In fact, various media can be used to deliver information and technology for seed farmers. The media could be print media, audio media, audio-visual media and media in the form of physical objects or real objects. Any media used, in principle, should be able to improve the effectiveness and the study process, especially in clarifying the material being studied in order to accelerate the behavioural changes (knowledge, skills, and attitudes) among the target group.

Elliot and Ephenia (2014) assert that extension should employ teaching and learning principle which is aimed at effecting behavioural change in the farmers. In addition, Somayeh (2017) also assert that "behavioural attitude is the most important determinant of experts' intention toward the use of the precision agriculture technologies". Now days, seed farmers feel that the extension done by the partners is still dominated by print and audio-visual media and have not optimally combines various types of media to support the implementation of the extension.

\section{Acknowledgement}

The researcher would like to give the deepest gratitude to the agency of Bogor Agriculture Institute (IPB), Syiah Kuala University (Unsyiah), The Government of North Aceh and seed farmers at "Sapue Pakat" Group in North Aceh.

\section{Conclusion}

In general, universities play significant role in innovation adoption process to rice seed farmers. The role is arranged by sequence; (1) implementing cultivation skill (2) strengthening farmer institution, (3) liaison with the government (4) guidance of transfer of technology, and (5) liaison with production market.

The perception of seed farmers on the characteristics of cultivation innovation of varieties IPB $3 \mathrm{~S}$ carried out by the extension partners are sequentially (1) have a level of relative advantage, (2) easy to try, (3) the level of compatibility, (4) can be observed, and (5) the level of complexity of innovation.

The role of partners both agricultural extension from the government or from the universities to seed farmers varieties of rice IPB $3 \mathrm{~S}$ in order are (1) the suitability of extension materials, (2) the intensity of extension, (3) the suitability of the method of extension and (4) the accuracy of using media.

Then it becomes very necessary for any parties involved in extension activities to facilitate the implementation of innovation. Using various media in extension activities is better to improve behaviour changes (knowledge, skills, and attitudes) in the application of good technology. The use of demonstration plot (plots) that are directly observable and visiting to institutions or success farmers is also a consideration. The use of different types of media such as audio media, audio-visual media and media in the form of physical objects or real objects also should be applied at every stage of the extension implementation.

\section{References}

Agussabti. 2002. The Farmers Autonomy in Adoption of Innovation Decision-Making (The Case of Vegetable Farmers in West Java Province). Bogor: Unpublished Disertation of Bogor Agricultural Institute.

Arthur TM. 1966. Getting Agriculture Moving: Essentials for Development and Modernization. New York: Frederick A. Preiger.

Elliot MZ. 2014. The role of extension as a profession is critical in delivering excellent services: an experience from Limpopo, South Africa. J Agr Sci 6:1-7. DOI:10.5539/ jas.v6n11p1. http://dx.doi.org/10.5539/jas.v6n11p1.

Elliot Z, Ephenia K. 2014. The role of extension in agricultural cooperative development in Limpopo. Int J Agr Ext 2:147152. Available from: http://escijournals.net/index.php/ IJAE/article/view/768/383[Accessed 11 July 2017].

Emmanuel T, Hajime K, Matsumura I, Mohamed E, Boubacar SB. 2015. Economic Analysis of the Role of Farmer Organizations in Enhancing Smallholder Potato Farmers' Income in Middle Guinea. J Agr Sci 7:123-137. DOI: $10.5539 /$ jas.v7n3p123.

Everett MR. 1983. Difusion of Innovation (3rd edition). New York: The Free Press.

Gana PO, Stephen RM. 2001. Partnership in agricultural extension: lessons from Chitwan (Nepal). Agric Resch Ext Netw. 114:1-12. Available from http://ibrarian.net/ navon/paper/PARTNERSHIP_IN_AGRICULTURAL_EXT ENSION_LESSONS_FR.pdf?paperid $=702808$. [Accessed $3^{\text {rd }}$ August 2017].

Gungor K, Esen O, Esra D. 2017. Factors Affecting Bureaucratic Information and Skills of Farmers; the Case of Tokat Province. Turjaf. 5: 3. Available at http://www.agrifoodscience.com/index.php/TURJAF/article/ view/995/476_[Accessed on 27 September 2017] DOI: https://doi.org/10.24925/turjaf.v5i3.231-238.995

Hakan A. 2015. Sustainable Agricultural Marketing Initiatives. Turjaf. 3:7. Available at http://www.agrifoodscience.com /index.php/TURJAF/article/download/446/181 [Accessed on 27 September 2017] DOI: https:// doi.org/ 10.24925/ turjaf.v3i7.595-603.446

John BC. 2000. The Cooperative Extension Service's Role in Running a Successful County Economic Development Program. JOE. 38:3 Available from: https://joe.org/joe/2000june/a3.php [Accessed 12 January 2018].

Matthew M, Bill G. 2006. Perceptions of Extension's Desirable Future and the Role of IT. JOE. 44:3 Available from: https://joe.org/joe/2006june/a1.php [Accessed 12 January 2018].

Mohammad SA. 2013. Agricultural sustainability:Implications for extension systems Afr J Agric Food Secur 1:48-53. Available from https://www.researchgate.net/publication/ 228627885_Agricultural_sustainability_Implications_for_ex tension_systems. [Accessed on 14th January 2018].

Muhammad M, Mehmood AN, Awais A, Fahad A, Muhammad AW, Muhammad AZ, Muhammad M, Abu UHZ, Muhammad WJ. 2017. Awareness and adoption level of fish farmers regarding recommended fish farming practices in Hafizabad, Pakistan. JSSAS http://dx.doi.org/10.1016 /j.jssas.2016.12.004 
Nancy KF. 2003. Transformative Learning in Extension Staff Partnerships: Facilitating Personal, Joint, and Organizational Change. JOE. 41:2 Available from: https://joe.org/joe/2003april/a1.php [Accessed 12 January 2018].

Patcha, Somsri P, Ganjanes A. 2017. Agricultural extension services to foster production sustainability for food and cultural security of glutinous rice farmers in Vietnam. Kas J Soc Sci. 38:74-80. Available from http://dx.doi.org/10.1016/j.kjss.2016.05.003[Accessed 17 September 2017].

Peter S, Brenda S, Tom D, Frank H. 2012. A Conceptual Process Model for Improving Youth Science Comprehension. JOE. 50:3 Available from: https://joe.org/joe/2012june/pdf/JOE_v50_3iw1.pdf [Accessed 26 December 2017].

Robert S, Amy H, Hannah C. 2010. Agricultural Extension Agents' Perceptions of Effective Teaching Strategies for Adult Learners in the Master Beef Producer Program. JOE. 48:3 Available from: https://joe.org/joe/2010june/rb2.php [Accessed 1 August 2017].

Rupak G, Md NA. 2011. Use of Participatory Exercise for Modelling the Adoption of Organic Agriculture. JOE. 49:3 Available from: https://www.researchgate.net/publication/236220352_Use_o f_Participatory_Exercise_for_Modelling_the_Adoption_of Organic_Agriculture [Accessed 26 December 2017].
Sapar, Amri J, Pang SA, Amiruddin, I Gusti PP. 2012. The performance agricultural extension workers and their impact at competence cacao farmers in four District South Sulawesi. J Peny. 8:1. 29-41. Available from https://media.neliti.com/media/publications/8482-ID-theperformance-agricultural-extension-workers-and-theirimpact-at-competence-ca.pdf_[Accessed 17 September 2017].

Scott DS, Theresa MF, Garee WE, James JC. 2006. Preparing Extension Professionals: The Ohio State University's Model of Extension Education. JOE. 44:4 Available from: https://joe.org/joe/2006august/a1.php [Accessed 12 January 2018].

Serah WKM, Monicah WMM, Jane NM, Daniel NM, Franklin SM. 2014. Client focused extension approach for disseminating soil fertility management in central Kenya. Int J Agr Ext 2:129-136. Available from: http://www.ku.ac.ke/schools/environmental/images/stories/r esearch2016/client_focussed_extension_research.pdf [Accessed 9 September 2017].

Somayeh TF, Kurosh RM. 2017. Determinants of Iranian agricultural consultants' intentions toward precision agriculture: Integrating innovativeness to the technology acceptance model. JSSAS. 16:280-286. http://dx.doi.org/10.1016/j.jssas.2015.09.003

Tesfamicheal W, Tahirou A, Arega A, Mekbib GH, Shiferaw F, Adetunji O, Victor M. 2017. Impacts of extension access and cooperative membership on technology adoption and household welfare. J Rur Stu 54: 223-233. Available from: http://creativecommons.org/licenses/by/4.0/_[Accessed 17 September 2017]. 